\title{
Sobrevivencia de Otocinclus spectabilis, en la etapa de levante, alimentado con dietas de diferente origen de la proteína
}

\author{
Survival of Otocinclus spectabilis, in levant stage, fed diets \\ of different protein origin
}

\section{Sobrevivência de Otocinclus spectabilis, na etapa de levante, alimentado com dietas de diferente origem da proteína}

\author{
Lina M. Ardila - Meléndez'; Jessica A. Albañil -Sanchez'; José A. Arias Castellanos
}

\author{
MVZ, Universidad Cooperativa de Colombia, Bucaramanga \\ 2 Biol, MSc, PhD, Profesor Universidad de los Llanos, Instituto de Acuicultura, Grupo Chamú Jiairé de peces ornamentales. \\ Email: jaariasc@hotmail.com
}

Recibido: septiembre 4 de $2012 \quad$ Aceptado: noviembre 29 de 2012

\begin{abstract}
Resumen
Los otocinclos son un grupo natural de peces loricaridos, que ocupan el segundo puesto dentro de los peces ornamentales de la captura que exporta Colombia. En la Orinoquia los alevinos y juveniles capturados de la especie son mantenidos cautivos en acuarios o estanques en tierra donde se les alimenta con raciones comerciales hasta conseguir la talla de venta, a esto último se le atribuye una de las principales causas de mortalidad. Con el propósito de explorar alternativas alimenticias que mejoren el proceso de levante, se evaluaron durante 45 días tres dietas con inclusión de proteína bruta del 21 $\%$ de diferente origen: tratamiento 1 = harina de pescado, tratamiento 2 = espirulina y tratamiento $3=$ harina de pescado y espirulina en partes iguales.

No se encontraron diferencias significativas con $\mathrm{p}<0.05$, para ganancia de peso pero sí para sobrevivencia así: T1 = 86.1 $\%>\mathrm{T} 2=69.4 \%>\mathrm{T} 3=62.3$, y ganancia de talla T1 $=0.85( \pm 0.03) \mathrm{cms}=\mathrm{T} 2=0.75( \pm 0.07) \mathrm{cms}>\mathrm{T} 3=0.67( \pm 0.09) \mathrm{cms}$. La especie acepto las tres dietas experimentales advirtiéndose que la presentación y oferta de las mismas no llamo la atención de los peces a lo largo del ensayo. Los tratamientos con inclusión de proteína de origen animal fueron los de mejor rendimiento lo que sugiere la necesidad de incluir proteína de origen animal en la ración.
\end{abstract}

Palabras clave: crecimiento, loricaridos, peso, requerimientos nutricionales, talla

Key words: growth, height, loricariids, nutritional requirements, weight 